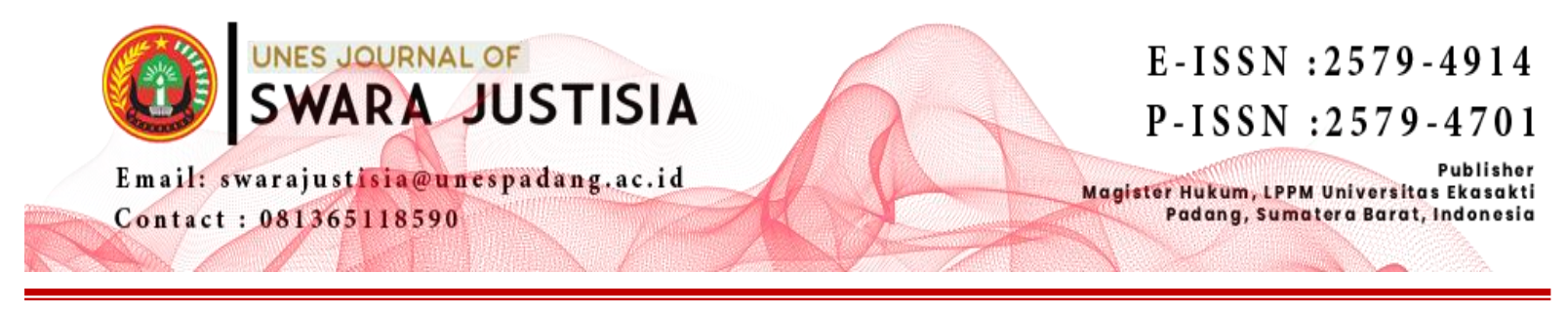

\title{
PERTIMBANGAN HAKIM TATA USAHA NEGARA DALAM PEMBATALAN SERTIPIKAT HAK ATAS TANAH YANG DIBEBANI HAK TANGGUNGAN (Analisis Putusan No.43/G/2019/PTUN.PDG dan Putusan No.44/G/2019/PTUN.PLG)
}

\author{
Almardian Asmar \\ Program Magister Ilmu Hukum,Universitas Ekasakti, Padang \\ Email: almardian.asmar@gmail.com
}

\begin{abstract}
Land has a dual function, namely as a social asset and a capital asset. The function of land as a social asset is a means of binding social unity among the community and the function of land as a capital asset because land has grown as a very important economic object. recorded in the land book. However, the certificate can be canceled at any time and the cancellation of the certificate of land rights will have a further impact on the process of guaranteeing the inherent Mortgage. The formulation of the problem in this research is, First, what is the consideration of the Judge of the State Administrative Court in canceling the certificate of ownership rights over land that is encumbered with mortgage rights? Second, What are the legal consequences of Certificate Cancellation based on a State Administrative Court Decision which has permanent legal force? The specification of this research is descriptive analysis. The approach used in this research is a normative juridical approach. It is called this because this research is a library research or document study which is carried out aimed only at written regulations or other legal materials. Based on the results of the research, it shows that (1) Consideration of State Administrative Court Judges in Cancellation of Certificate of Ownership of Land Burdened with Mortgage Rights (Case Analysis of Decision No. 43 / G / 2019 / PTUN.PDG) is to consider all evidence submitted by the parties to make a decision by describing the evidence relevant to the case and the judge's consideration is also based on the prevailing laws and regulations. (2) The legal consequence of the cancellation of a certificate based on the decision of the State Administrative Court which has permanent legal force is to cancel a decision, so that the result of the issuance of the cancellation decision is seen from the verdict of the court that has obtained permanent legal force (inkracht). If the Court Decision declares a certificate of ownership rights over land cancellation, then this will cause the land that has been issued a certificate of ownership rights on it to return to its original status, namely State land.
\end{abstract}

Keywords: Judge's Consideration, certificate cancellation

\begin{abstract}
ABSTRAK
Tanah memiliki fungsi ganda, yaitu sebagai aset sosial dan aset modal. Fungsi tanah sebagai aset sosial merupakan sarana pengikat kesatuan sosial di antara masyarakat dan fungsi tanah sebagai aset modal karena tanah telah tumbuh sebagai objek ekonomi yang sangat penting. dicatat dalam buku tanah. Namun sertipikat tersebut sewaktu-waktu dapat dibatalkan dan pembatalan sertipikat hak atas tanah akan berdampak lebih lanjut pada proses penjaminan Hak Tanggungan yang melekat. Rumusan masalah dalam penelitian ini adalah, Pertama, apa
\end{abstract}


pertimbangan Hakim Pengadilan Tata Usaha Negara dalam membatalkan sertifikat hak milik atas tanah yang dibebani hak tanggungan? Kedua, Apa akibat hukum dari Pembatalan Sertifikat berdasarkan Putusan PTUN yang telah mempunyai kekuatan hukum tetap? Spesifikasi penelitian ini adalah deskriptif analisis. Pendekatan yang digunakan dalam penelitian ini adalah pendekatan yuridis normatif. Disebut demikian karena penelitian ini merupakan penelitian kepustakaan atau studi dokumen yang dilakukan hanya ditujukan pada peraturan tertulis atau bahan hukum lainnya. Berdasarkan hasil penelitian menunjukkan bahwa (1) Pertimbangan Hakim Pengadilan Tata Usaha Negara dalam Pembatalan Sertifikat Hak Milik atas Tanah Hak Tanggungan (Analisis Perkara Putusan No. 43/G/2019/PTUN.PDG) adalah mempertimbangkan semua alat bukti yang diajukan para pihak untuk mengambil keputusan dengan memaparkan alat bukti yang relevan dengan perkara dan pertimbangan hakim juga berdasarkan peraturan perundang-undangan yang berlaku. (2) Akibat hukum dari pembatalan suatu akta berdasarkan putusan Pengadilan Tata Usaha Negara yang telah mempunyai kekuatan hukum tetap adalah batalnya suatu putusan, sehingga hasil dari dikeluarkannya putusan pembatalan tersebut dilihat dari putusan Pengadilan Tata Usaha Negara yang telah mempunyai kekuatan hukum tetap. pengadilan yang telah memperoleh kekuatan hukum tetap (inkracht). Apabila Putusan Pengadilan menyatakan batalnya sertipikat hak milik atas tanah, maka hal ini akan menyebabkan tanah yang telah dikeluarkan sertipikat hak milik di atasnya kembali ke status semula yaitu tanah Negara.

Kata kunci: Pertimbangan Hakim, pembatalan sertifikat

\section{PENDAHULUAN}

Keberadaan tanah tidak dapat dilepaskan dari segala aktifitas manusia baik dalam pergerakan ekonomi, sosial, politik dan budaya seseorang maupun komonitas masyarakat. Hal ini disebabkan karena tanah memiliki kedudukan dan fungsi yang sangat penting bagi setiap manusia dalam menjalankan aktifitas dan melanjutkan kehidupannya sehari hari.

Sehubungan dengan itu maka untuk meletakkan dasar untuk memberikan kepastian hukum mengenai hak atas tanah bagi pemilik tanah yang diatur dalam Pasal 19 ayat (2) Undang-Undang No.5 Tahun 1960 tentang Peraturan Dasar Pokok-Pokok Agraria selanjutnya didalam penelitian ini di singkat UUPA yang menyatakan pendaftaran tersebut dalam ayat (1) Pasal ini meliputi: pengukuran perpetaan dan pembukuan tanah, pendaftaran hak-hak atas tanah dan peralihan hak-hak tersebut, pemberian surat-surat tanda bukti hak, yang berlaku sebagai alat pembuktian yang kuat.

Dalam praktik sehari-hari, perolehan hak atas tanah sangat banyak terjadi akibat jual beli tanah melalui Pejabat Pembuat Akta Tanah ( PPAT ). Akta jual beli yang dibuat oleh dan dihadapan PPAT adalah bertujuan untuk pengalihan hak milik atas tanah dari si penjual kepada si pembeli. Akta jual beli tersebut adalah sebagai surat bukti peralihan hak milik atas tanah, yang membuktikan bahwa peralihan hak milik atas tanah itu sudah dilakukan sesuai dengan ketentuan hukum yang berlaku. ${ }^{1}$

Selanjutnya mengenai sertipikat menurut Pasal 32 Peraturan Pemerintah No. 24 Tahun 1997 tentang Pendaftaran Tanah selanjutnya disebut PP No. 24 Tahun 1997 tentang Pendaftaran Tanah yang menyatakan bahwa sertipikat hak milik merupakan surat tanda bukti

${ }^{1}$ Kansil, Christine ST Kansil, Kitab Undang Undang Hukum Agraria, Sinar Grafika, Jakarta 2001, hlm 
hak yang berlaku sebagai alat pembuktian yang kuat mengenai data fisik dan data yuridis yang termuat di dalamnya, sepanjang data fisik dan data yuridis tersebut sesuai dengan data yang ada dalam surat ukur dan buku tanah yang bersangkutan.

Menurut Ter Haar sebagaimana dikutip dalam Jurnal Zuman Malaka dan Habib Adjie bahwa terjadinya hubungan yang erat antara tanah dengan manusia dikarenakan tanah merupakan tempat tinggal, tanah yang memberi kehidupan, tanah dimana manusia dimakamkan, dan hubungannya bersifat magis religius. belum lagi jika melihat Negara Indonesia sebagai negara agraris, sehingga tanah benar-benar mempunyai peranan penting. Yang menjadi persoalan selanjutnya adalah munculnya tarik-menarik dari berbagai pihak untuk berebut akses tanah, karena fungsi tanah begitu penting bagi setiap orang yang dihadapakan dengan keterbatasan atas ketersedian tanah itu sendiri. ${ }^{2}$

Ketentuan dalam Pasal 3 PP Nomor 24 Tahun 1997 Tentang Pendaftaran Tanah ditengah tujuan pendaftaran tanah antara lain memberikan kepastian hukum dan perlindungan hukum terhadap pelepasan hak dengan alat bukti kuat. Kemudian ini mampu dijadikan sebagai acuan dan sebagai salah satu jalan keluar bagi permasalahan seperti sengketa hak milik atas tanah, pasca pemerintah dalam pasal berperan memberikan kepastian hukum dan perlindungan hukum kepada masyarakat selaku pemegang hak atas bidang tanah tertentu, satuan rumah susun dan hak lain serta penegasan mengenai pentingnya hak sah atas kepemilikan tanah, satuan rumah susun dan hak lain dalam urusan administrasi pertanahan. Untuk itu ketika terjadi sengketa hak milik atas tanah seharusnya mampu diselesaikan secara efektif dengan pasal tersebut.

Dalam pendaftaran tanah, terdapat 5 (lima) asas pendaftaran tanah yang harus benarbenar dilaksanakan, salah satunya asas aman yang mengandung makna hati-hati, cermat, dan teliti, agar tidak terjadi suatu kekeliruan data yang dikumpulkan, sehingga kepastian hukum dapat tercapai.

Untuk melaksanakan tujuan pendaftaran tanah maka pemberian jaminan kepastian hukum, yang terdapat dalam Pasal 19 ayat (1) UU No.5 Tahun 1960 tentang UUPA telah menetapkan kegiatan pendaftaran tanah yang bersifat memberikan jaminan kepastian hukum atau rechts Kadester. UUPA menetapkan bahwa yang berkewajiban melaksanakan pendaftaran tanah adalah pemerintah dan pemegang hak atas tanah dengan cara mendaftarkan hak atas tanah tersebut maka pemilik tanah akan mendapatkan sertipikat untuk tanah yang mereka miliki.

Dengan demikian PP No. 24 Tahun 1997 pendaftaran tanah sebagaimana tercantum pada Pasal 3 huruf a PP No. 24 Tahun 1997 merupakan tujuan utama pendaftaran tanah yang diperintahkan oleh Pasal 19 ayat 8A, disamping memberikan perlindungan hukum juga dimaksudkan terciptanya suatu pusat informasi mengenai bidang-bidang tanah sehingga pihak yang berkepentingan termasuk Pemerintah agar dengan mudah dapat memperoleh data yang diperlukan dalam mengadakan perbuatan hukum mengenai bidang-bidang tanah dan satuan-satuan rumah susun yang sudah didaftar serta terselenggaranya tertib administrasi dibidang pertanahan.

\footnotetext{
${ }^{2}$ Zuman Malaka dan Habib Adjie, Tanggung Jawab Kantor Pertanahan terhadap Terbitnya Sertifikat Ganda Studi Kasus Putusan Kasasi MA No. 162 K/TUN/2012, Jurnal Universitas Narotama Surabaya, AlQanun, Vol. 20, No. 2, Desember 2017, hlm 30
} 
Tanah yang sudah memiliki sertipikat dapat melakukan peralihan hak atas tanah tersebut. Peralihan tersebut terjadi apabila presedur peralihan hak sudah dilakukan secara lengkap dan benar, maka beralihlah tanah hak milik itu dari si penjual kepada si pembeli, sehingga si pembeli kemudian menjadi pemegang hak milik berikutnya atas tanah tersebut. Sebagai pemegang hak milik atas tanah, maka si pemilik mendapat bukti hak kepemilikan atas tanah berupa sertipikat hak milik atas tanah yang merupakan surat Keputusan Tata Usaha Negara. ${ }^{3}$ Sedangkan, Akta jual beli yang dibuat oleh PPAT, adalah perjanjian yang dibuat oleh pejabat umum, dan bukan Surat Keputusan Tata Usaha Negara, sehingga dengan demikian Surat Akta Jual Beli dengan Surat Sertipikat hak milik atas tanah adalah dua hal yang masing-masing mempunyai posisi hukum berbeda.

Akan tetapi hak atas tanah tersebut juga dapat dibatalkan meskipun sudah mempunyai sertipikat. yang menyebutkan bahwa yang dimaksud dengan pembatalan hak atas tanah adalah pembatalan keputusan pemberian hak atas tanah atau sertipikat hak atas tanah karena keputusan tersebut mengandung cacat hukum administrasi dalam penerbitannya atau untuk melaksanakan putusan pengadilan yang telah memperoleh ketetapan hukum tetap.

Pembatalan hak atas tanah, karena cacat hukum administratif dalam penerbitannya,dapat dilakukan karena (1) permohonan dari yang berkepentingan atau (2) oleh Pejabat yang berwenang tanpa permohonan.

Permohonan hak atas tanah karena cacat hukum administratif melalui permohonan dari yang berkepentingan diajukan langsung kepada Menteri atau Pejabat yang ditunjuk atau melalui Kepala Kantor Pertanahan, yakni Badan Pertanahan Nasional di tingkat Kabupaten/Kota (Kantor Pertanahan). ${ }^{4}$ Menurut Pasal 107 Peraturan Menteri Negara Agraria/ Kepala BPN No.9 Tahun 1999 disebutkan bahwa cacad administrasi dimaksud adalah:

a) Kesalahan prosedur

b) Kesalahan penerapan peraturan perundang-undangan

c) Kesalahan subjek hak

d) Kesalahan objek hak

e) Kesalahan jenis hak

f) Kesalahan perhitungan luas

g) Terdapat tumpang tindih hak atas tanah

h) Data yuridis atau data fisik tidak benar, atau

i) Kesalahan lainnyayang bersifat hukum administrasi.

Sedangkan, pembatalan hak atas tanah karena cacat hukum administratif tanpa melalui permohonan oleh Pejabat yang berwenang dilaksanakan apabila diketahui adanya cacat hukum administratif dalam proses penerbitan keputusan pemberian hak atau sertipikatnya tanpa adanya permohonan dan Pembatalan hak atas tanah karena putusan pengadilan yaitu pembatalan hak atas tanah karena melaksanakan putusan pengadilan yang telah memperoleh kekuatan hukum tetap diterbitkan atas permohonan yang berkepentingan, dimana permohonan tersebut diajukan langsung kepada Menteri atau Kepala Kantor Wilayah atau melalui Kantor Pertanahan. Pasal 119 - 123 Peraturan Menteri Negara Agraria/ Kepala BPN No.9 Tahun 1999.

\footnotetext{
${ }^{3}$ Yurisisprudensi Mahkamah Agung RI, NO. 1588 K / Pdt / 2001 /, tanggal 30 Juni 2004

${ }^{4}$ Pasal 106 Peraturan Menteri Negara Agraria/ Kepala BPN No.9 Tahun 1999
} 
Di Indonesia, sertipikat hak-hak atas tanah berlaku sebagai alat bukti yang kuat sebagaimana ditegaskan dalam Pasal 19 ayat (2) huruf c UUPA dan Pasal 32 ayat (1) Peraturan Pemerintah Nomor 24 Tahun 1997 Tentang Pendaftaran Tanah. Pemberian sertipikat dimaksudkan untuk mencegah sengketa kepemilikan tanah. Dengan memiliki sertipikat, pemilik tanah dapat melakukan perbuatan hukum apa saja sepanjang tidak bertentangan dengan undang-undang, ketertiban umum, dan kesusilaan. Selain itu sertipikat mempunyai nilai ekonomi yang tinggi apabila dijadikan jaminan utang dengan hak tanggungan atas tanah. Meskipun telah mendapat pengakuan dalam UUPA, sertipikat belum menjamin kepastian hukum kepemilikannya karena dalam peraturannya sendiri memberi peluang dimana sepanjang ada pihak lain yang merasa memiliki tanah dapat menggugat pihak yang namanya tercantum dalam sertipikat secara keperdataan ke peradilan umum atau menggugat Kepala Kantor Pertanahan yang bersangkutan ke Pengadilan Tata Usaha Negara, atau gugatan yang menyangkut teknis administrasi penerbitannya. ${ }^{5}$

Sertifikat tersebut bukan hanya berguna sebagai penjamin dan memberikan kepastian hukum kepada pemiliknya, tetapi sertipikat tersebut juga dapat digunakan sebagai penjaminan terhadap hak tanggungan. UUPA juga telah menyesuaikan serta lembaga jaminan hak atas tanah yang disebut hak tanggungan yang dapat dibebankan pada hak milik, hak guna bangunan dan hak guna usaha sebagaimana di tegaskan dalam Pasal 25, Pasal 33 dan Pasal 39 UUPA yang akan diatur dengan Undang-Undang (Pasal 51 UUPA). Kemudian lahirlah UU No.4 Tahun 1996 tentang Hak Tanggungan sebagai wujud realisasi dari perintah UUPA tersebut, dan UUHT secara terang menyatakan bahwa Hak Tanggungan adalah satu-satunya lembaga jaminan atas tanah.

Hak tanggungan memang dirancang sebagai hak jaminan yang terkuat, dengan ciri khas eksekusi mudah dan pasti, akan tetapi dalam prakteknya banyak menimbulkan kendalakendala. Seperti terjadi dalam hal nasabah bank atau debitur cidera janji pada saat akan diadakan lelang karena cidera janji maka debitur mengadakan perlawanan atau gugatan untuk menunda lelang yang dimohonkan oleh bank dengan macam-macam alasan antara lain jumlah hutang menurut debitur tidak sesuai dengan jumlah yang telah tercantum di akta perjanjian kredit atau perjanjian hutang piutang.

Sertifikat hak milik atas tanah yang diterbitkan berdasarkan kepada akta jual beli, dibuat melalui tata cara dan presedur yang sedemikian ketat, yang tujuannya agar sedapat mungkin kebenaran data- data atas tanah yang dituangkan didalamnya dapat dijamin kebenarannya. Demikian juga halnya mengenai penerbitan sertipikat hak milik atas tanah yang dibuat berdasarkan akta jual beli, sebelum sertipikat hak milik itu diterbitkan, maka harus didahului pengumuman selama 30 hari untuk pendaftaran tanah secara sistematik dan 60 hari untuk pendaftaran tanah secara sporadis sebagaimana diatur dalam Pasal 26 ayat ( 1 ) Peraturan Pemerintah No. 24 tahun 1997 tentang Pendaftaran Tanah, untuk memberi kesempatan kepada pihak - pihak tertentu mengajukan keberatan, sebelum sertipikat hak milik atas itu diterbitkan, yang mengandung arti pula bahwa sertipikat hak milik atas tanah itu, tidak saja diberikan kekuatan hukum akan tetapi juga diberikan kekuatan mengikat, sebagaimana halnya suatu undang-undang saat disahkan oleh DPR dan Pemerintah akan

${ }^{5}$ Gunardi, Markus Gunawan, Kitab Undang Undang Hukum Kenotariatan, Raja Grafindo Persada ,Jakarta, 2007, hlm 156 
mempunyai kekuatan hukum, dan pada saat diumumkan dalam Lembaran negara akan mempunyai kekuatan mengikat. ${ }^{6}$

Tenggang waktu pengumuman kepada publik selama 60 hari sebelum sertipikat hak milik atas tanah diterbitkan, apabila dihubungkan dengan ketentuan Pasal 5 Undang-Undang No.5 Tahun 1986 tentang Peradilan Tata Usaha Negara dirubah dengan Undang-Undang No. 9 Tahun 2004 dirubah dengan Undang-Undang No.51 tahun 2009 tentang Peradilan Tata Usaha Negara dalam Pasal 55 berbunyi ;

"Gugatan hanya dapat dilakukan dalam tenggang waktu sembilan puluh hari terhitung sejak diterimanya atau diumumkannya Keputusan badan atau Pejabat Tata Usaha negara".

Ketentuan ini mengisyaratkan seakan- akan setiap gugatan terhadap ke-absahan sertipikat besar kemungkinannya akan lampau waktu, karena sebelum sertipikat itu diterbitkan sudah di lakukan pengumuman selama 2 bulan oleh Pejabat Badan Pertanahan Nasional. Akan tetapi dalam praktek peradilan; menyangkut pembatalan sertipikat hak milik atas tanah oleh Pengadilan Tata Usaha Negara, ketentuan Pasal 55 tersebut ditafsirkan sedemikian rupa melalui Surat Edaran Mahkamah Agung ( SEMA. MA ) No. 2 tahun 1991, tanggal 9 Juli 1991 No. MA / Kumdil / 213 / VII / K / 1991, pada bagian 3 berbunyi ;

"Bagi mereka yang tidak dituju oleh suatu Keputusan Tata Usaha Negara tetapi yang merasa kepentingan dirugikan maka tenggang waktu sebagaimana dimaksudkan dalam pasal 55 UU No.5 tahun 1986 dirubah dengan Undang-Undang No.9 tahun 2004 dihitung secara kasuistis sejak saat ia merasa kepentingannya dirugikan oleh Keputusan tata Usaha negara dan mengetahui adanya keputusan tersebut “.

Dengan adanya SEMA tersebut, secara yuridis empiris dan berdampak pada proses hukum terjadinya gugatan pembatalan atas sertipikat hak milik atas tanah tanpa batas waktuuntuk sertipikat hak atas tanah yang terbit kapanpun, karena tegang waktu pengajuan gugatan sebagaimana diatur dalam SEMA tersebut diatas dihitung sejak saat ; yang merasa dirugikan mengetahui Keputusan tata Usaha Negara tersebut. Sema MA No.2 Tahun 1991 ini, seakan akan mengesampingkan begitu saja ketentuan pasal 55 Undang-Undang No. 5 Tahun 1986 yang telah dirubah Undang-Undang No.9 tahun 2004, seakan mengikuti pembuktian hukum pertanahan dengan sistem publikasi negatif secara murni, padahal pemerintah sebelum menerbitkan sertipikat sudah melakukan upaya yang sedemikian preseduralnya untuk dapat memberikan kebenaran data tanah se-optimal mungkin sebagaimana ditentukan dalam Pasal 32 ayat ( 2 ) Peraturan Pemerintah No. 24 tahun 1997 yang berbunyi ;

"Dalam hal suatu bidang tanah sudah diterbitkan sertipikat secara sah dan atas nama orang atau badan hukum yang memperoleh tanah tersebut dengan etikad baik dan secara nyata menguasainya, maka pihak lain yang merasa mempunyai hak atas tanah itu, tidak dapat lagi menuntut pelaksanaan hak tersebut apabila dalam tenggang waktu 5 tahun sejak diterbitkannya sertipikat itu tidak mengajukan keberatan secara tertulis kepada pemegang sertipikat itu atau kepada Kepala Kontor Pertanahan yang

\footnotetext{
${ }^{6}$ Soehino, Hukum Tata Negara, Teknik Perundang-undangan, Liberty, Yogyakarta, 1981, hlm 154.
} 
bersangkutan ataupun tidak mengajukan gugatan ke Pengadilan mengenai penguasaan atan atau penerbitan sertipikat tersebut".

Apabila dilihat dari sisi pandang Presedur dan Tata Cara Penerbitan sertipikat hak milik atas tanah sebagaimana diatur dalam Peraturan Menteri Pertanian dan Agraria No 2 Tahun 1962, dan juga dilihat dari sisi pandang ketentuan Pasal 32 ayat ( 2 ) PP No. 24 Tahun 1997, serta ketentuan psl. 55 Undang-Undang No. 5 Tahun 1986 dirubah dengan UndangUndang No.9 Tahun 2004. Atau ; apakah SEMA No. 2 tahun 1991 dapat dipandang sebagai pengisi kekosongan hukum, mengingat Pasal 55 Undang-Undang No.5 Tahun 1986 yang telah diperbarui dengan Undang-Undang No.9 tahun 2004 hanya mengatur tentang tenggang waktu mengajukan gugatan untuk Keputusan Tata Usaha Negara yang dituju saja, sedangkan untuk pihak ketiga yang dirugikan oleh penerbitan Keputusan Tata Usaha Negara oleh Badan atau Pejabat Tata Usaha Negara sebagai pihak yang tidak dituju oleh Keputusan Tata Usaha Negara tersebut (dalam hal ini; sertipikat Hak Milik) belum dijangkau oleh Pasal 55 UndangUndang No.5 Tahun 1986 yang telah diperbarui dengan Undang-Undang No.9 tahun 2004. Pembatalan sertipikat hak milik atas tanah oleh Pengadilan Tata Usaha Negara, adalah sudah merupakan praktek hukum yang lazim, yang menyebabkan pemilik tanah berdasarkan bukti sertipikat hak milik atas tanah menjadi kehilangan hak miliknya, padahal hak milik itu terbit berdasarkan jual beli yang sah berdasarkan bukti akta jual beli yang dibuat oleh PPAT. Menjadi pertanyaan, apakah sipembeli tanah tersebut dapat terus menguasai tanah yang dibelinyai tu, berdasarkan akt jual beli, yang tidak dibatalkan oleh Pengadilan Tata Usaha Negara? Apakah putusan Pengadilan Tata Usaha Negara itu mempunyai kekuatan eksekutorial, dimana pemegang sertipikat hak milik atas tanah yang sertipikatnya dibatalkan dapat dihukum oleh Pengadilan Tata Usaha Negara untuk menyerahkan tanah itu kepada pihak yang menang. Memperhatikan persoalan-persoalan hukum disekitar pembatalan sertipikat hak milik atas tanah oleh Pengadilan Tata Usaha Negara dan bagaimana akibat hukumnya terhadap akta jual beli atas tanah yang dibuat oleh PPAT, menyebabkan kami tertarik untuk mengkajinya dalam bentuk penelitian dengan judul: Pertimbangan Hakim Tata Usaha Negara Dalam Pembatalan Sertipikat Hak Atas Tanah Yang Dibebani Hak Tanggungan (Analisis Putusan No. 43/G/2019/PTUN.PDG dan Putusan No. 44/G/2019/PTUN.PLG)

\section{METODE PENELITIAN}

Metode yang digunakan adalah hanya pendekatan yuridis normatif dengan hanya menggunakan data sekunder yang diperoleh melalui studi kepustakaan. Data tersebut kemudian di analisis secara kualitatif dan disajikan dalam bentuk deskriptif kualitatif.

\section{PEMBAHASAN}

A. Pertimbangan Hakim Pengadilan Tata Usaha Negara Dalam Pembatalan Sertipikat Hak Milik Atas Tanah Yang Dibebani Hak Tanggungan Dalam Putusan No. 43/G/2019/Ptun.Pdg Dan Putusan No. 44/G/2019/Ptun.Plg

\section{Dalam Putusan No. 43/G/2019/Ptun.Pdg}

Pasal 53 Undang-Undang No.9 Tahun 2004 tentang Pembentukan Atas Undang-Undang No.5 tahun 1986 tentang Peradilan Tata Usaha Negara berbunyi: 
bahwa orang atau badan hukum perdata yang merasa kepentingannya dirugikan oleh suatu Keputusan Tata Usaha Negara dapat mengajukan gugatan tertulis kepada pengadilan yang berwenang yang berisi tuntutan agar Keputusan Tata Usaha Negara yang disengketakan itu dinyatakan batal atau tidak sah, dengan atau tanpa disertai tuntutan ganti rugi dan/atau direhabilitasi. Adapun alasan-alasan yang dapat digunakan dalam gugatan adalah:

1) Keputusan Tata Usaha Negara yang digugat itu bertentangan dengan peraturan perundang-undangan yang berlaku;

2) Keputusan Tata Usaha Negara yang digugat itu bertentangan dengan asas- asas umum pemerintahan yang baik.

Berkaitan dengan sertipikat tanah, sertipikat tanah dikeluarkan oleh, dalam hal ini Badan Pertanahan Nasional selaku Badan Tata Usaha Negara ditujukan kepada seseorang atau badan hukum (konkret, individual) yang menimbulkan akibat hukum pemilikan atas sebidang tanah yang tidak memerlukan persetujuan lebih lanjut dari instansi atasan atau instansi lain (final). ${ }^{7}$

Berdasarkan Yurisprudensi Mahkamah Agung Republik Indonesia Nomor 88.K/TUN/1993 tanggal 7 September 1993 tentang Kompetensi Absolut "Meskipun sengketa itu terjadi akibat dari adanya surat keputusan pejabat, tetapi jika dalam perkara tersebut menyangkut hak kepemilikan atas tanah, maka gugatan tersebut harus diajukan terlebih dahulu ke Pengadilan Umum karena merupakan sengketa Perdata.

Badan Pertanahan Nasional merupakan badan yang kewenangannya yang dilimpahkan secara delegasi oleh pemerintah dan merupakan Pejabat TUN yang berwenang mengeluarkan sertipikat hak atas tanah melalui Kantor Pertanahan Kabupaten atau Kota. Dalam hal sebagai Pejabat TUN maka menurut Soehino perbuatan sebagai Pejabat TUN dapat dikelompokkan menjadi 3 (tiga) macam perbuatan-perbuatan TUN, yaitu: Mengeluarkan atau menetapkan keputusan, yang disebut ketetapan administrasi atau beschikking; Mengeluarkan peraturan atau regeling; Melakukan perbuatan materiil atau materiele daad, atau perbuatan wajar. ${ }^{8}$

Berdasarkan uraian singkat di atas, maka dapat diambil pengertian bahwa BPN sebagai Pejabat TUN mengeluarkan sertipikat hak atas tanah yang mana sertipikat tersebut tergolong (karena memenuhi syarat) sebagai KTUN yang merupakan penetapan tertulis, berbentuk ijin, ${ }^{9}$ bersifat konkrit, individual dan final, dan timbulnya sertipikat ini menimbulkan hak dan kewajiban bagi pemegang hak maupun kepada orang lain secara tidak langsung, dan dikeluarkan berdasarkan peraturan perundang-undangan yang berlaku.

Pembatalan sertipikat hak atas tanah sebagai tanda bukti hak, bilamana dikaitkan dengan sistem publikasi di Indonesia, maka menganut sistem publikasi negatif yang mengarah kepada publikasi positif, dimana pemegang sertipikat

7 Z.A. Sangaji, Kompetensi Badan Peradilan Umum dan Peradilan Tata Usaha Negara Dalam Gugatan Pembatalan Sertifikat Tanah, Bandung : Citra Adit ya Bakti, 2003, hlm. 36.

${ }^{8}$ Soehino, Asas-Asas Hukum Tata Usaha Negara, Liberty, Yogyakarta, 1998, hlm 54.

${ }^{9}$ Menurut Prins, ijin adalah ketetapan yang ditujukan kepada suatu obyek yang tidak dilarang dan hal yang tidak diijinkan adalah terbatas. Periksa Diana Halim Koentjoro, Op. Cit., hlm 65-66 
dianggap sebagai pemilik hak atas tanah. Mengenai kekuatan hukum sertipikat sebagai tanda bukti hak, ketentuan Pasal 32 PP Pendaftaran Tanah menyatakan bahwa Sertipikat merupakan surat tanda bukti hak yang berlaku sebagai alat pembuktian yang kuat mengenai data fisik dan data yuridis yang termuat didalamnya, sepanjang data fisik dan data yuridis tersebut sesuai dengan data yang ada dalam surat ukur dan buku tanah hak yang bersangkutan.

Kasus pembatalan sertipikat dalam penelitian penulisan ini bermula dari Penggugat telah mengajukan gugatan tanggal 11 Desember 2019, yang didaftarkan di Kepaniteraan Pengadilan Tata Usaha Negara Padang pada tanggal 18 Desember 2019, dengan Register Perkara Nomor: 43/G/2019/ PTUN.PDG, dan telah diperbaiki tanggal 20 Februari 2020, Penggugat mengemukakan pada pokoknya. Dalam gugatan tersebut terdapat 7 sertipikat yang menjadi objek gugatan dan 2 diantara sedang menjadi objek tanggungan.

Upaya administrasi dengan berpedoman pada Pasal 75 Undang-Undang No. 30 Tahun 2014 tentang Administrasi Pemerintahan, pada tanggal 3 September 2019 saat inzaghe Penggugat barulah mengetahui tentang objek perkara, sesuai dengan Peraturan Mahkamah Agung R.1. No. 6 Tahun 2018 tentang Pedoman Penyelesaian Sengketa Administrasi Pemerintahan yakni 21 (dua puluh satu) hari kerja, maka pada tanggal 23 September 2019 Penggugat menyurati Tergugat melalui Surat No.T/133/14400G/HK.02/IX/2019, perihal Keberatan dan Surat No. T/148/14400G/HK.02/X/2019 tanggal 10 Oktober 2019, perihal Banding Administratif ke Kantor Wilayah Pertanahan Provinsi Sumatera Barat, yang pada intinya mengajukan upaya administratif berupa keberatan, dimana Penggugat menyatakan keberatan atas diterbitkannya Objek Gugatan yang secara nyata telah merugikan Penggugat karena diterbitkan diatas tanah milik Penggugat, namun sampai dengan gugatan ini diajukan, Tergugat tidak pernah melakukan penyelesaian atas upaya administratif tersebut. Kepala Kantor Pertanahan Kota Sawahlunto yang berkedudukan di Simpang Kolok, Kota Sawahlunto yang merupakan wilayah hukum Pengadilan Tata Usaha Negara Padang menurut ketentuan Pasal 54 ayat (1) Undangundang No. 51 tahun 2009 tentang Perubahan Kedua atas Undang-Undang No. 5 tahun 1986 tentang Peradilan Tata Usaha Negara, gugatan sengketa Tata Usaha Negara diajukan kepada Pengadilan yang berwenang yang daerah hukumnya meliputi kedudukan Tergugat dikarenakan Tergugat menerbitkan surat a quo, yang merupakan putusan Pejabat Tata Usaha Negara (beschikking) yang konkret, individual, dan final, bertentangan dengan peraturan perundang-undangan yang berlaku dan pada waktu mengeluarkan keputusan (Objek Gugatan) telah menggunakan wewenang untuk tujuan lain dari maksud diberikan wewenang tersebut, sehingga telah merugikan kepentingan Penggugat sebagaimana diatur dalam Pasal 53 ayat (1) jo pasal 53 ayat (2) huruf a dan b Undang-undang No. 5 Tahun 1986 sebagaimana telah diubah terakhir kali dengan Undang-undang No. 51 Tahun 2009 tentang Peradilan Tata Usaha Negara.

Dari penjelasan diatas, pihak Pengadilan telah mempertimbangkan seluruh alat bukti yang disampaikan para pihak namun untuk mengambil putusan hanya menguraikan alat bukti yang relevan dengan perkara ini; 
Mengingat, Undang-Undang Nomor 5 Tahun 1986 tentang Peradilan Tata Usaha Negara sebagaimana terakhir diubah dengan Undang-Undang Nomor 51 Tahun 2009 tentang perubahan kedua atas Undang-Undang Nomor 5 Tahun 1986 tentang Peradilan Tata Usaha Negara, Undang-Undang Nomor 30 Tahun 2014 tentang Administrasi Pemerintah, serta peraturan perundang-undangan dan ketentuan hukum lain yang berkaitan.

\section{Putusan 44/G/2019/PTUN.PLG}

Didalam putusan tersebut menyatakan bahwa objek sengketa dalam perkara ini adalah Sertipikat Hak Milik Nomor 2010/Kel.Karang Raja, tanggal 17 Oktober 1979 Nama Pemegang Hak terakhir Albertus Hendra, dengan Surat Ukur No. 1361/Karang Raja/2016 tanggal 05 September 2016, Luas 1011 M2 yang terletak di Kelurahan Karang Raja Kecamatan Prabumulih Timur Kota Prabumulih Provinsi Sumatera Selatan. Dalam Pasal 47 juncto Pasal 50 Undang-Undang Nomor 5 Tahun 1986 Tentang Peradilan Tata Usaha Negara juncto Pasal 1 angka 10 UndangUndang Nomor 51 Tahun 2009 Tentang Perubahan Kedua atas Undang-Undang Nomor 5 Tahun 1986 Tentang Peradilan Tata Usaha Negara, dengan obyek sengketa berupa keputusan tata usaha negara sebagaimana diatur dalam Pasal 1 angka 9 Undang-Undang Nomor 51 Tahun 2009 ditambah dengan Pasal 1 angka 7 juncto Pasal 87 Undang-Undang Nomor 30 Tahun 2014 Tentang Administrasi Pemerintahan, dengan pembatasan tertentu karena lahirnya peraturan perundang-undangan yang baru dan pembatasan karena yurisprudensi Mahkamah Agung RI, pada pokoknya sengketa pertanahan yang dapat diadili di Peradilan Tata Usaha Negara adalah terkait administrasi penerbitan keputusan tata usaha negara berupa sertipikat hak atas tanah atau keputusan- keputusan pejabat tata usaha negara yang berhubungan dengan tanah.

De'action atau no interest no action yang dimaknai pada pokoknya hanya yang memiliki kepentingan saja dapat mengajukan gugatan pada Pengadilan Tata Usaha Negara bahwa lebih lanjut terdapat 2 (dua) tolok ukur untuk menentukan kepentingan yang dirugikan, yaitu: ${ }^{10}$

1) Menunjuk kepada nilai yang harus dilindungi oleh hukum, artinya terdapat nilai baik yang bersifat menguntungkan maupun yang merugikan yang ditimbulkan atau apa yang menurut nalar dapat diharapkan akan timbul oleh keluarnya suatu Keputusan TUN atau suatu penolakan.

2) Menunjuk pada kepentingan proses, artinya apa yang hendak dicapai dengan melakukan suatu proses gugatan yang bersangkutan, bahwa berdasarkan pemeriksaan setempat yang dilaksanakan pada tanggal 29 Januari 2020 di lokasi tanah yang menjadi bagian dari objek sengketa, Majelis Hakim menemukan fakta hukum bahwa baik Penggugat, Tergugat maupun Tergugat II Intervensi menunjuk tanah yang sama yaitu pada sebagian tanah yang diakui kepemilikannya oleh Penggugat, yang mana saat ini di atasnya telah dibangun ruko oleh Tergugat II Intervensi (vide Berita Acara Pemeriksaan Setempat tanggal 29 Januari 2020).

${ }^{10}$ Indroharto, Usaha Memahami Undang- undang tentang Peradilan Tata Usaha Negara, Buku II, Pustaka Sinar Harapan, Jakarta, 1994, hlm 37-38 
Lebih lanjut terhadap dalil Penggugat yang menjadikan Grondkaart sebagai alas hak, Majelis Hakim berpendapat meskipun Grondkaart tidak dapat disamakan dengan sertipikat yang secara rigid dan jelas tersirat dalam undang-undang sebagai alat bukti hak yang terkuat, namun keberadaan Grondkaart tetap diakui sebagai salah satu bentuk bukti kepemilikan aset perusahaan negara karena dibuat oleh lembaga pertanahan yang berwenang pada saat pembuatannya dan termuat dalam ketentuan perundang-undangan antara lain.

Berdasarkan tujuan Peradilan Tata Usaha Negara yang salah satunya adalah untuk menyelesaikan sengketa tata usaha negara, kemudian dihubungkan dengan dikabulkannya gugatan Penggugat untuk menyatakan batal objek sengketa, yang tentu menimbulkan akibat hukum bagi Tergugat II Intervensi selaku pemegang hak terakhir dan pihak yang menguasai serta telah mendirikan bangunan pada bidang tanah yang menjadi bagian dari objek sengketa, selanjutnya Majelis Hakim berpendapat bahwa pembatalan objek sengketa tidak serta merta menghilangkan hak dan kepentingan Tergugat II Intervensi dalam menguasainya, karena Tergugat II Intervensi adalah pembeli yang beritikad baik dan dilindungi oleh perundang-undangan, selain itu berdasarkan bukti P-16 sampai dengan P- 30, diperoleh fakta hukum pula mengenai adanya sewa menyewa antara Penggugat dengan warga masyarakat yang menggunakan lahan yang menjadi bagian dari aset Penggugat, karena meskipun lahan-lahan yang disewakan tersebut tidak berbatasan langsung dengan bidang tanah yang menjadi bagian dari objek sengketa namun bisa dijadikan salah satu rujukan bagi Tergugat II Intervensi dan Penggugat untuk menyelesaikan sengketa ini.

\section{B. Akibat Hukum Pembatalan Sertipikat Berdasarkan Putusan Pengadilan Tata Usaha Negara Yang Telah Mempunyai Kekuatan Hukum Tetap Dalam Putusan No. 43/G/2019/Ptun.Pdg Dan Putusan No. 44/G/2019/Ptun.Plg}

Pembatalan sertipikat hak milik atas tanah sebagai pelaksanaan putusan pengadilan yang telah memperoleh kekuatan hukum tetap didasarkan atas permohonan dari pihak yang berkepentingan, sebagaimana yang diatur dalam Pasal 59 ayat (1) Peraturan Kepala Badan Pertanahan Nasional Nomor 3 Tahun 2011 tentang Pengelolaan Pengkajian dan Penanganan Kasus Pertanahan, yang menetapkan bahwa "Proses penerbitan, peralihan dan/atau pembatalan hak atas tanah untuk melaksanakan putusan pengadilan yang telah berkekuatan hukum tetap, dilakukan berdasarkan adanya pengaduan/permohonan pihak yang berkepentingan. Selanjutnya permohonan pembatalan sertipikat hak milik atas tanah dapat diajukan kepada Kepala Kantor Pertanahan atau Kepala Kantor Wilayah Badan Pertanahan Nasional atau Kepala Badan PertanahanNasional, dimana berdasarkan Pasal 59 (3) Peraturan Kepala Badan Pertanahan Nasional Nomor 3 Tahun 2011 tentang Pengelolaan Pengkajian dan Penanganan Kasus Pertanahan.

Akibat hukum dari pembatalan Putusan No.43/G/2019/PTUN.PDG yaitu berdasarkan fakta-fakta hukum tersebut yang telah dan dijabarkan di atas dan dihubungkan dengan ketentuan-ketentuan peraturan perundang-undangan sebagaimana diuraikan diatas, maka pengadilan berpendapat bahwa penerbitan dan peralihan hak Objek Sengketa aquo secara prosedur dan substansi bertentangan dengan ketentuan Pasal 
103 (1) dan Pasal 133 (1), (3) Peraturan Menteri Negara Agraria/ Kepala Badan Pertanahan Nasional Nomor 3 Tahun 1997 Tentang Ketentuan Pelaksanaan Peraturan Pemerintah Nomor 24 Tahun 1997 Tentang Pendaftaran Tanah, oleh karenanya obyek sengketa a quo harus dinyatakan batal dan karena objek sengketa dinyatakan batal, Tergugat diwajibkan untuk mencabut objek sengketa.

Berdasarkan pertimbangan tersebut maka Pengadilan berpendapat gugatan Penggugat dikabulkan seluruhnya dan oleh karena gugatan Penggugat dikabulkan seluruhnya, Tergugat dan Tergugat II Intervensi dinyatakan sebagai pihak yang kalah dihukum membayar biaya perkara secara tanggung renteng sejumlah yang tercantum dalam amar putusan ini serta bahwa Pengadilan telah mempertimbangkan seluruh alat bukti yang disampaikan para pihak namun untuk mengambil putusan hanya menguraikan alat bukti yang relevan dengan perkara ini. Sedangkan akibat hukum dari pembatalan putusan No.44//G/2019/PTUN.PLG yaitu berdasarkan tujuan Peradilan TataUsaha Negara yang salah satunya adalah untuk menyelesaikan sengketa tata usaha negara, kemudian dihubungkan dengan dikabulkannya gugatan Penggugat untuk menyatakan batal objek sengketa, yang tentu menimbulkan akibat hukum bagi Tergugat II Intervensi selaku pemegang hak terakhir dan pihak yang menguasai serta telah mendirikan bangunan pada bidang tanah yang menjadi bagian dari objek sengketa, selanjutnya Majelis Hakim berpendapat bahwa pembatalan objek sengketa tidak serta merta menghilangkan hak dan kepentingan Tergugat II Intervensi dalam menguasainya, karena Tergugat II Intervensi adalah pembeli yang beritikad baik dan dilindungi oleh perundang- undangan, selain itu berdasarkan bukti P-16 sampai dengan P-30, diperoleh fakta hukum pula mengenai adanya sewa menyewa antara Penggugat dengan warga masyarakat yang menggunakan lahan yang menjadi bagian dari aset Penggugat, karena meskipun lahan-lahan yang disewakan tersebut tidak berbatasan langsung dengan bidang tanah yang menjadi bagian dari objek sengketa namun bisa dijadikan salah satu rujukan bagi Tergugat II Intervensi dan Penggugat untuk menyelesaikan sengketa ini.

\section{PENUTUP}

\section{A. Kesimpulan}

Pertimbangan Hakim Pengadilan Tata Usaha Negara Dalam Pembatalan Sertipikat Hak Milik Atas Tanah Yang Dibebani Hak Tanggungan (Analisis Kasus Putusan No. 43/G/2019/PTUN.PDG dan Putusan No.44/G/2019/PTUN.PLG) adalah bahwa dalam pengadilan berpendapat bahwa penerbitan dan peralihan hak Objek Sengketa aquo secara prosedur dan substansi bertentangan dengan ketentuan Peraturan Menteri Negara Agraria/ Kepala Badan Pertanahan Nasional Nomor 3 Tahun 1997 Tentang Ketentuan Pelaksanaan Peraturan Pemerintah Nomor 24 Tahun 1997 Tentang Pendaftaran Tanah, oleh karenanya obyek sengketa a quo harus dinyatakan batal, serta Pengadilan telah mempertimbangkan seluruh alat bukti yang disampaikan para pihak namun untuk mengambil putusan hanya menguraikan alat bukti yang relevan dengan perkara ini.

Akibat hukum Pembatalan Sertipikat berdasarkan Putusan Pengadilan Tata Usaha Negara yang telah mempunyai kekuatan hukum tetap yaitu amar yang memerintahkan Pejabat TUN (dalam hal ini BPN) untuk mencabut sertipikat 
tersebut. Apabila terdapat putusan pengadilan yang telah memperoleh kekuatan hukum tetap, dimana sebagai tindak lanjut dari Putusan Pengadilan yang telah memperoleh kekuatan hukum tetap yaitu diterbitkannya keputusan pembatalan, karena hakim tidak dapat secara langsung membatalkan suatu keputusan, sehingga akibat dari penerbitan Keputusan pembatalan adalah dilihat dari amar putusan pengadilan yang telah memperoleh kekuatan hukum tetap (inkracht) tersebut. Apabila Putusan Pengadilan menyatakan batal suatu Sertipikat Hak Milik Atas Tanah, maka hal ini menyebabkan tanah yang telah terbit Sertipikat Hak Milik diatasnya kembali kepada status semula yaitu tanah Negara.

B. Saran

Pertimbangan Hakim dalam menyelesaikan perkara mengenai sengketa hak milik atas tanah dan untuk lebih menggali masalah-masalah dalam hukum pertanahan yang berkaitan dengan sengketa hak milik atas tanah, majelis hakim dapat menambah alat bukti saksi dengan menghadirkan ahli dibidang pertanahan (saksi ahli) untuk meminta saran kepadanya sebelum mengeluarkan putusan. Hakim yang menangani suatu perkara dapat memperoleh keterangan atau penjelasan tambahan dari para ahliyang ahli dibidangnya untuk memperkuat dasar putusan dan mengantisipasi agar putusan yang dikeluarkan tidak menjadi putusan yang kurang tepat, sehingga tidak ada lagi pihakpihak yang dirugikan karena hakim kurang menggali keterangan dan penjelasan mengenai permasalahan yang sedang ditanganinya.

Diperlukan adanya suatu sosialisasi dan peran aktif dari Panitera Pengadilan kepada pihak yang berperkara di Pengadilan mengenai hak yang dapat diperoleh atau dilaksanakan dalam hal ini perlindungan hukumnya, sehingga tidak ada lagi pihak yang dirugikan karena kurangnya pemahaman mengenai prosedur hukum.

\section{DAFTAR PUSTAKA}

\section{Buku Teks:}

Adrian Sutedi, Hukum Hak Tanggungan, Sinar Grafika, Jakarta, 2010

Ali Achmad Chomzah, Hukum Pertanahan Seri Hukum Pertanahan 1 Pemberian Hak Atas

Tanah Negara Seri Hukum Pertanahan II Sertifikat Dan Permasalahannya, Prestasi Pustaka, 2002

Boedi Harsono, Hukum Agraria Indonesia, Himpunan Peraturan-Peraturan Hukum Tanah, Djambatan, Jakarta, 2004

Eddy Ruchiyat, Politik Pertanahan Sebelum Dan Sesudah Berlakunya UUPA UndangUndang Nomor 5 Tahun 1960, Alumni, Bandung, 1995

Gunardi, Markus Gunawan, Kitab Undang Undang Hukum Kenotariatan, Raja Grafindo Persada, Jakarta, 2007

Maria S.W. Sumarjono, Puspita Serangkum Aneka Masalah Hukum Agraria, Andi Offset, Yogyakarta, 1982

Effendy Hasibuan, “Dampak Pelaksanaan Eksekusi Hipotik Dan Hak Tanggungan Terhadap Pencairan Kredit Macet Pada Perbankan Di Jakarta, Laporan Penelitian, Universitas Indonesia Pascasarjana (S3) Bidang Studi Ilmu Hukum, 1997

9 Tim Penyusun Kamus-Pusat Pembinaan dan Pengembangan Bahasa, Kamus Besar Bahasa Indonesia, Balai Pustaka, Jakarta, 1989, 
Tim penyusun Kamus Pusat Pembinaan dan pengembangan Bahasa, Kamus Besar Bahasa Indonesia, Edisi kedua, cet. 1,Jakarta: Balai Pustaka, 1991

\section{Peraturan Perundang-Undangan:}

Undang-Undang No. 4 Tahun 1996 Tentang Hak Tanggungan Atas Tanah Beserta BendaBenda yang Berkaitan dengan Tanah

Kitab Undang-Undang Hukum Perdata; Undang-Undang Nomor 5 Tahun 1960 tentang

Peraturan Dasar Pokok-Pokok Agraria Undang-Undang No.5 Tahun 1986 Tentang Peradilan Tata Usaha Negara

Peraturan Menteri Negara Agraria/Kepala Badan Pertanahan Nasional No. 3 Tahun 1999 tentang Pelimpahan Kewenangan Pemberian dan Pembatalan Keputusan Pemberian Hak Atas Tanah Negara 